\title{
Management Styles And Cultural Differences: Bridging The Productivity Gap In The Implementation Of Information Technology
}

John E. Merchant (E-mail: merchant@csus.edu), California State University at Sacramento Sylnovie Merchant (E-mail: smerchant@csus.edu), California State University at Sacramento

\begin{abstract}
This research project reports on a study of cultural values (work values) of different nationalities around the world as it relates to the implementation of Information Technology. It is an on-going study of workers from several nations and what cultural/work values they bring to the work environment. For multinational corporations with worldwide information systems, this study provides them with realizations of what approaches to take in dealing with different nationals. At the same time, it is an attempt to develop and test a model for classifying nationalities based upon their cultural orientations and the type of orientation that they feel most comfortable working in: formal or informal.
\end{abstract}

\section{Introduction}

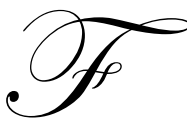

rom a business perspective, the political and economic effectiveness of the United States in the global arena will depend on individuals and collective abilities to communicate competently with people from other cultures. To date, however, U.S. businesspeople who were sent overseas by U.S.-based multinational corporations have not fared as well as their European and Asian counterparts; an estimated 20 to 50 percent of these Americans returned home early from their international assignments, primarily because of the cultural differences (Joynt and Warner, 1996). At a time when the resurgent forces of nationalism and ethnic and linguistic consciousness so directly affect global realities, the United States requires far more reliable capabilities to communicate with its allies, analyze the behaviors of potential adversaries, and earn the trust and sympathies of the uncommitted. Yet, there is a widening gap between these needs and the American competence to understand and deal successfully in a world in flux. These political connections of the United States to other countries is matched by the global interdependence that characterizes U.S. economic relationships. The future success of American businesses, therefore, is contingent on their interactions with foreign nations and obviously dependent on how well they understand the culture of other people and are able to communicate with them.

We know that success in a corporation's performance is significantly affected by the culture of the organization. Hunger and Wheelen (1995) point out that an optimal culture is one that best supports the mission and strategy of the company of which it is a part. In the context of American corporations, one could easily subscribe to their argument. However, in our global economy, many organizations with worldwide operations are a mix of Americans, Europeans, Asians, etc. working together, each with his/her own orientation to life and work. Given the fact that 25 percent to 50 percent of an employee's behavior on the job is culturally determined (Gannon, 1994), one needs to understand the cultural values behind these employees. This is especially so as the nature of business and competition evolves from a local and national focus to a more global, international focus. With it, we must expand our understanding of the nature of work from that of a single cultural perspective to a multi-cultural perspective. For management, the critical challenge is to help their employees become more competitive on the job and to relate better to the global problems and opportunities of the company (Garland \& Farmer, 1986). Therefore companies 
need to develop not just a generally favorable culture but also specific cultural characteristics to maximize the performance of their employees (Yip, 1995). They can do this in two ways. One is to understand the cultural orientation of the employees in their companies; second, they must understand and adjust to the work environment desired by these individuals.

\section{Previous Research}

Individuals bring cultures of origin to work (Gibson and Zellmer-Bruhn, 2001) that reflect their particular ongoing histories in various cultural contexts, such as national cultures. Cross-cultural research has established that in addition to national culture explaining variations in attitudes, it is also related to social behaviors such as aggression, conflict resolution, social distance, helping, dominance, conformity, and obedience, as well as decisionmaking and leadership behaviors (Gannon et al, 1994; Gibson and Zellmer-Bruhn, 2001; Hofstede, 1980; Shane, 1994; Triandis, 1994). In cognitive terms, national culture is viewed as a set of shared meanings transmitted by a set of mental programs that control responses in a given context (Hofstede, 1980; Shweder and LeVine, 1984). The basic thesis of a cognitive approach to culture is that processing frameworks acquired in one culture persist and influence behavior even though circumstances change. In this manner, culture guides our choices, commitments, and standards of behavior (Erez and Earley, 1993)

It is not enough to suggest that concepts vary across organizational cultures; it is also important to examine systematic variation due to specific aspects of culture. Researchers have demonstrated that patterns of orientations (O’Reilly, Chatman, and Caldwell, 1991; Kabanoff, Waldersee, and Cohen,1995; Kabanoff and Holt, 1996) and practices (Hofstede et al., 1990) can be used to explain the differences in organizational cultures. Kabanoff and colleagues (Kabanoff, Waldersee, and Cohen,1995; Kabanoff and Holt, 1996) identified a set of nine orientationsperformance, reward, authority, leadership, teamwork, commitment, normative orientation, participation, and affiliation - that can be discerned from organizational documents such as annual reports and demonstrated that different patterns of orientations were associated with different ways of portraying and communicating change.

Other authors showed that individual performance varied depending on the cultural background of the group studied. For instance, the collectivistic orientation of Chinese workers suggests more of a tendency toward group-based performance incentives than Americans (Earley, 1993).

Some studies have shown that heterogeneous groups perform better than homogeneous groups on complex problem-solving tasks (Shaw, 1983; Steiner, 1972; Ruhe, 1978). More recent findings, however, indicate newly formed, culturally diverse groups would not be effective in problem solving. Yet, this diminishes with the amount of time the group spends together, with the heterogeneous group gradually achieving the level of effectiveness equivalent to that of the homogeneous group (Watson, Kumar, and Michaelsen, 1993).

Other researchers found that teams that value and endorse dissent, that adopt fluid structures, and that recognize how they are embedded in a social and political network will succeed, even in a highly individualistic culture (Nahavandi, 1994). One interesting argument is that organizational culture is strongly influenced by the characteristics of the industry in which the company operates (Gordon, 1991).

Other authors have discovered relationships between cultural values and employment longevity (Sheridan, 1992), culture and the direct influence on service quality (Klein, Masi, Weidner, 1995), strength of a company's culture and the long-term performance of the company (Gordon \& DiTomaso, 1993), and corporate culture and its impact on a company's economic success (Rollins, 1993).

From a motivation-performance viewpoint, researchers have cited the relationship between sub-groups such as age, gender, income level, etc., and performance (Kovach, 1995), and the correlation between productivity and voluntarily formed work team in China (Jin, 1993). A study across three cultures (US, Russia and China) found differences in a supportive culture for organizations in the three nations (Silverthorne, 1992). Previous research by Merchant, $(1994,1995,1996,1997)$ found significant differences in various nationals and the type of boss they preferred - as well as differences in 14 other variables. 
Obviously, cross-cultural management requires more than just a fleeting knowledge of the country involved. A major hindrance to one's successful assimilation into a culture is generalizing about the country and stereotyping the various subcultures that exist there. Adding to the difficulty is the grouping of individuals from culturally different origins and requiring them to work together effectively. In fact, many mergers and acquisitions fail due to a misunderstanding of the cultural dynamics by one of the parties (Cartwright and Cooper, 1993).

As corporations (both foreign and domestic) move more and more into the global arena, the managers involved need to understand that employees in other nations do not share their values or orientations to the job - or the organization. To have a productive worker from a nation other than America (and in some cases, in America itself) management must clearly recognize the differences inherent in the cultural up-bringing of the employees. The educational, religious, family, geographical, historical and cultural factors of a nation have shaped a person who may be either a strength or a weakness to the goals of one's organization. To be successful in the international market place, one has to have a supportive and progressive culture in place within the organization. Without understanding the cultural ramifications of the various national and ethnic personalities working in the organization, the possibility of competitive advantage will be difficult and cumbersome. This paper, part of an-going research project for the last four years, has identified some of the key factors of what employees from different nations desire in an ideal job. Coupled with their cultural orientation, this research provides an exploratory endeavor to correlate multiple variables so that a study of the means to obtain maximum peak performance can be developed and used for those involved in our global business economy.

The aim of this study is to explore the correlation between certain cultural values of employees in other countries and the orientations they would desire in an organization. Specifically, based upon their culture: what type of manager would relate to their cultural orientations. Coupled with their cultural values, the authors have developed a four-cell matrix, which allows one to align the cultural orientation of nationals with an appropriate formal versus informal organizational culture.

\section{The Role Of Culture}

As early as 1952, researchers identified more than 160 definitions of culture, and it is now estimated that Culture has been defined in approximately 400 ways (Ferrero, 1994). To undertake a large inventory would therefore be unrealistic. The purpose here is merely to supply the reader with a brief introduction to the notion, which is why a rough simplification is inevitable. There is a common view in research concerning the basic meaning of culture: individually, we are all different, but share similar experiences with those who grew up in the same surroundings, in the same type of society as us. In this way, there are cultural differences between, for example: nations, regions, social classes, generations, men and women, religious, ethnic, and linguistic groups, minorities, and professions and organizations (those who work in a certain company and who share a corporate culture).

Culture becomes visible in a variety of ways. Symbols, heroes, rituals and values can summarize the main elements of manifestations. One can also simply make the distinction between practices (containing the three first elements), and values. Practices are relatively superficial elements of a culture, expressed in collective habits, such as the way in which people greet each other, their eating habits, the way in which meetings are conducted, status symbols, language and special professional vocabulary, clothing style, communication style, etc.

Values, on the on the other hand, are not visible in the same way as practices are. They form the deepest and most "hidden" dimension of culture, and are often unconscious to people. Values are one of the first things a child learns from its parents. To understand the consequences of culture on our behavior and values, we must therefore go back to childhood. During that period, our parents taught us how to behave and think (consciously and unconsciously). We were rewarded for a certain behavior and punished for another. Later this occurred in school and at work. We were taught, among others things, about what is: Good versus Evil, Clean versus Dirty, Beautiful versus Ugly, Natural versus Unnatural, Normal versus Abnormal, Logical versus Illogical, Rational versus Irrational, and Fair versus Unfair. These values are broad tendencies that individuals will prefer as opposed to other conditions.. The important point is that they were taught in the context of the environment in which one was raised and educated. That is, fair versus unfair in one society may not be the same as in another society. 
An operational definition of Culture, therefore, is:

- $\quad$ Something that is shared by all, or almost all members of some social group.

- $\quad$ Something that the older members of the group try to pass on to the younger members.

- $\quad$ Something (as in the case of morals, laws and customs) that shapes behavior, or that structures one's perception of the world (Francesco and Gold, 1998).

Therefore, increased knowledge about such factors as what motivates people from other cultures, how they will react under certain circumstances, in which way they make decisions and want decisions to be made, the way they communicate, how they want contracts to be stipulated, their performance to be evaluated, can contribute to a reduction of the already high levels of uncertainty linked to cross-cultural management. Furthermore, this knowledge, or cultural competence, can help reduce costs linked to negotiation and the quality of productivity through an improvement of the management of human resources.

\section{Data And Methods}

This paper has evolved out of an on-going study of employees in countries around the world and the orientations they prefer in the work place. At this point, analysis has been completed on results for employee values in Australia, China, France, Norway, South Korea, Thailand, Singapore, Vietnam, Malaysia, England, Japan, Hong Kong, Taiwan, Indonesia, Germany and the United States. Over 2,500 respondents have participated in the study. Surveys are currently being collected in Mexico, India, Egypt and Chile. The cultural orientations of the employees considered are those identified by Roger Harrison as Organizational Ideologies of: Power orientation, Role orientation, Task orientation, and Person (or Self) orientation (Harrison, 1975). A description of each ideology follows.

Power Orientation: A power-oriented culture has the intention of completely dominating its environment, eliminating its competition in the process. Often these organizations are seen buying and selling companies with ruthless disregard for employee welfare. The power-oriented organization's primary interests are control and expansion. Individuals who survive in this environment tend to exhibit the same characteristics of the organization. They rely upon the boss to be strong, decisive and firm.

Role Orientation: A role-oriented culture tends to have a preoccupation with legitimacy, legality and responsibility. There is a strong emphasis on hierarchy and status, but the commitment to legitimacy and legality tends to moderate this. Rules and regulations are strictly followed, and as much value is placed on stability and respectability as on competence. Employees in these organizations desire the authority that only comes from the "formal" system.

Task Orientation: The task-oriented culture places the highest priority on task achievement. This is the reason the organization exists, and nothing is permitted to interfere with the attainment of this goal. Unlike the power or role orientation, there is no ideological commitment to authority, rules or regulations. Organizational structure, staffing and legitimacy exist for the sole purpose of accomplishing a task. Employees look for management to provide the tools and the environment needed to accomplish the job.

Person (Self) Orientation: A person, or self-oriented, culture exists for the purpose of serving the needs of its members. In a reversal of roles, the other three types of organizations are primarily concerned with how its members can be effectively used to its benefit. In contrast, the person-oriented organization is examined by its members to ensure the members' needs are met. Individuals influence each other through example, helpfulness and caring. Decisions in the organization are made through consensus revolving around the needs and values of the individuals in the organization. Schematically, the orientations, placed on a continuum, are shown in Figure 1. 
Figure 1

\section{Orientation Continuum}

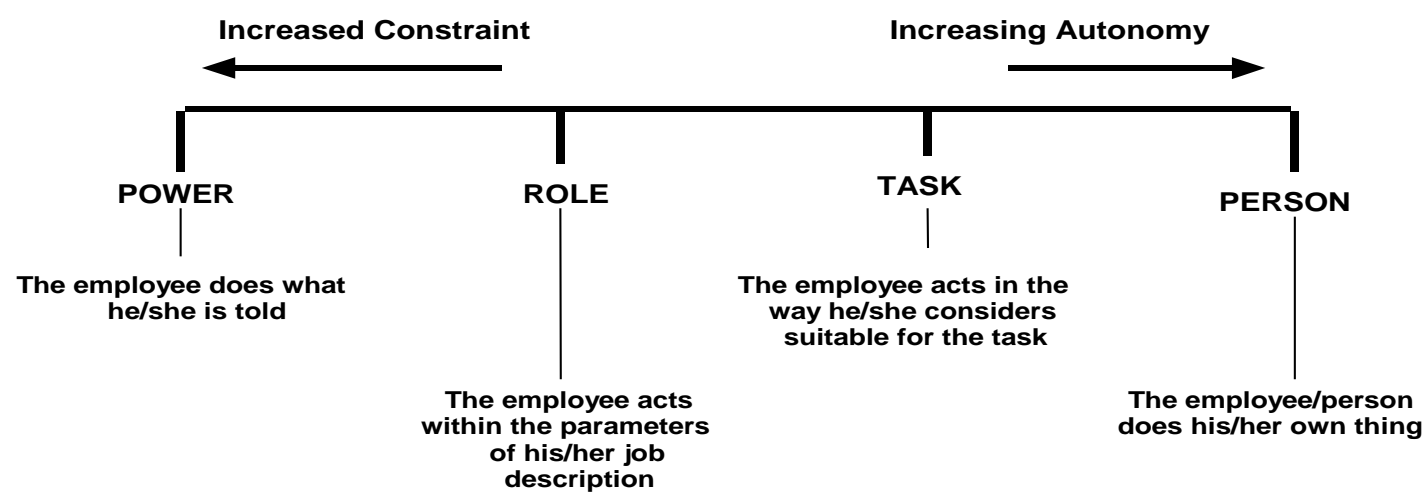

Adapted from Cartwright and Cooper (1993)

\section{Findings}

The overall finding of the study of the 16 nations so far indicate the majority of responses (63\% \%) fall into the Task Oriented column; that is, they are motivated to do their best at their assigned tasks and seek support to do the best job possible. The second orientation is Role $(25 \%)$, and indicates that they prefer to do what is the official role they were hired to perform; the third is Self $(7 \%)$, which indicates that they desire involvement with the mission and goals of the organization; and the last is Boss (5\%), that indicate that they will do what they are told to do as they trust the leader to provide direction and look-out for their interests. However, when you break it down by nation, the picture changes dramatically. Specifically, looking merely as to "what type of boss do you desire", the key element in any organizational relationship, we find the majority of respondents in a nation indicating their preferences as follows:

- $\quad$ Power Oriented - Taiwan, China, Malaysia, Hong Kong, Singapore, Thailand, Indonesia, Vietnam and Korea;

- $\quad$ Role Oriented - Germany;

- $\quad$ Task Oriented - Australia, Norway and France; and

- $\quad$ Self Oriented - United States, England, and Japan.

Based on the preceding, therefore, an American manager dealing with employees oriented toward Power, needs to understand that he/she will be looked upon to direct the activities of the employees, while at the same time, insuring that their security and well-being are taken care of. For an American manager involved with Task oriented employees, he/she must assign the task, provide the support they need and allow them to proceed on their own. For the manager dealing with Role oriented employees, he/she needs to insure that the requirements for the job, the standards and behavior expected are clearly spelled out in job descriptions, rules and regulations, etc. Finally, for Self oriented individuals, the manager needs to involve them from the beginning, soliciting their inputs and participate as almost an equal. A model was developed as a benefit to those managers who may be directing the activities of foreign nationals.

\section{Model}

The model in Table 1 attempts to represent two factors: (1) the work cultures of nationalities either desiring a formal or informal organization culture and (2) their orientation toward either people or process. 
Table 1

Developed Model

\begin{tabular}{|c|c|c|c|}
\hline \multicolumn{2}{|c|}{$\begin{array}{l}\text { CULTURE-ORIENTATION } \\
\text { MATRIX }\end{array}$} & \multicolumn{2}{|c|}{ ORIENTATION } \\
\hline & & PEOPLE & PROCESS \\
\hline $\bar{C}$ & $\begin{array}{l}\mathbf{F} \\
\mathbf{O} \\
\mathbf{R} \\
\mathbf{M} \\
\mathbf{A} \\
\mathbf{L}\end{array}$ & $\begin{array}{c}\text { LEADER/BOSS } \\
\text { (CELL 1) }\end{array}$ & $\begin{array}{c}\text { ROLE } \\
\text { (CELL 2) }\end{array}$ \\
\hline $\mathbf{R}$ & $\begin{array}{c}\mathbf{I} \\
\mathbf{N} \\
\mathbf{F} \\
\mathbf{O} \\
\mathbf{R} \\
\mathbf{M} \\
\mathbf{A} \\
\mathbf{L}\end{array}$ & $\begin{array}{l}\text { INDIVIDUAL } \\
\qquad \text { (CELL 3) }\end{array}$ & $\begin{array}{r}\text { TASK/JOB } \\
\text { (CELL 4) }\end{array}$ \\
\hline
\end{tabular}

The horizontal axis represents the cultural orientation of the employee in a nation, either reflecting his cultural bias toward people or a process. The vertical axis represents the two forms of organization culture - either formal or informal that an employee would feel comfortable working in.

Horizontal and Formal (cell 1) represents an employee who is quite comfortable in following the lead and direction of his manager. In fact, this employee would prefer to have clear direction and close supervision from his/her boss who is in the traditional or legalistic position of supervision. The employee is basically saying "tell me what you want me to do and how - I trust you and will follow your directions as I know that you will look out for my welfare as long as I am doing a good job."

Horizontal and Formal (cell 2) represents an employee who prefers to abide by the rules, regulations and procedures that have been outlined for his job. He/she has allegiance to the role that he/she has been hired to perform and feels that as long as everyone follows the dictates of the rules then it will be a productive company. This employee is in effect, the ideal bureaucratic person. His/her orientation is "don't ask me to do more than what is outlined in my duties and responsibilities."

Horizontal and Informal (cell 3) represent an employee who is oriented to people - and himself/herself - in order to grow and develop. He/she wants involvement and consultation over his/her role and work assignment so that he/she can become more efficient and feels the company will benefit from his/her increased knowledge and skills. The boss should be one who involves this employee. He/she wants to be consulted and involved in what needs to be done - with a special emphasis on "I want to grow and develop within the company."

Horizontal and Informal (cell 4) represent an employee who, like his brethren in cell 3, is not concerned with the trappings of authority or role delineation. His/her perception is that a job needs to be done and he/she is capable of doing so and looks to a boss to provide the necessary tools and environment so he/she can do his job. $\mathrm{He} / \mathrm{she}$ is a very independent individual in an organization. His/her basic orientation is, "I am good, I know my job, give me the tools and let me go to work."

In essence, a Formal Organization Culture provides a basis for authority for the employees, whether it be traditional, legal, or charismatic legitimacy, and is representative of a mechanistic organization, with rules, regulations and practices that are expected, and accepted. The employees are extremely comfortable working in an environment such as that. On the other hand, an Informal Organization Culture does not represent authority-based activities, it is more like the organic type organization where informality is the mode of operation. Productivity for 
these employees comes from involving or supporting the activities of their predisposition to operate more-or-less on their own. The employees desiring this cultural-orientation appear to be representatives of knowledgeable and self-assured individual, who are quite comfortable in this environment and do not desire either direct control or detailed rules and regulations to dictate their activities.

\section{Model Application}

For the purpose of this paper, an analysis of the key variables (manager) will be discussed in relation to a proposed model for evaluating and classifying nationalities by a typology. One way to view the application of this model is to view it as a series of decision boxes in assessing the pre-disposition of the employee due to his cultural orientation. The question posed to the respondents was: What Type of Manager Do You Want to Work For? What type do you feel comfortable with? The four choices were:

a. One who is strong, decisive, firm, fair, protective, generous and indulgent to loyal subordinates; or

b. One who is impersonal and correct; demands from the subordinate only that which is required by the formal system; or

c. One who is egalitarian and uses his authority to obtain the needed resources to complete the job; or

d. Concerned with the personal needs and values of others, using his position to provide satisfying and growth-stimulating work opportunities.

Obviously, a is Power (Cell 1), b is Role (Cell 2), c is Self (Cell 3), and d is Task (Cell 4). Therefore, one who is oriented to relying overwhelming on his manager for direction, close supervision, and rewards in the work place would feel very comfortable in cell 1 . Nationalities who fall into this category, based on this research effort, include most employees from Asia, such as China, Thailand, Vietnam, and Indonesia. This finding is supported by the research of Hofstede (1980) in that all of these societies have a Large Power Distance orientation. The employee that is oriented to a set of rules and guidelines to fulfill his responsibilities would obviously feel comfortable in cell 2. In this research, Germans fall into this category. In cell 3, Informal person-oriented would be those nationalities that are predisposed to being involved in the work assignments. Nationalities here include England, United States and Japan. Finally, for cell 4, these nationalities want an informal structure, which concentrates on getting the job done and looks to the manager for support. Australia, Norway and France fall into this category. Table 2 illustrates these orientations.

Table 2

Cultural-Orientation Matrix

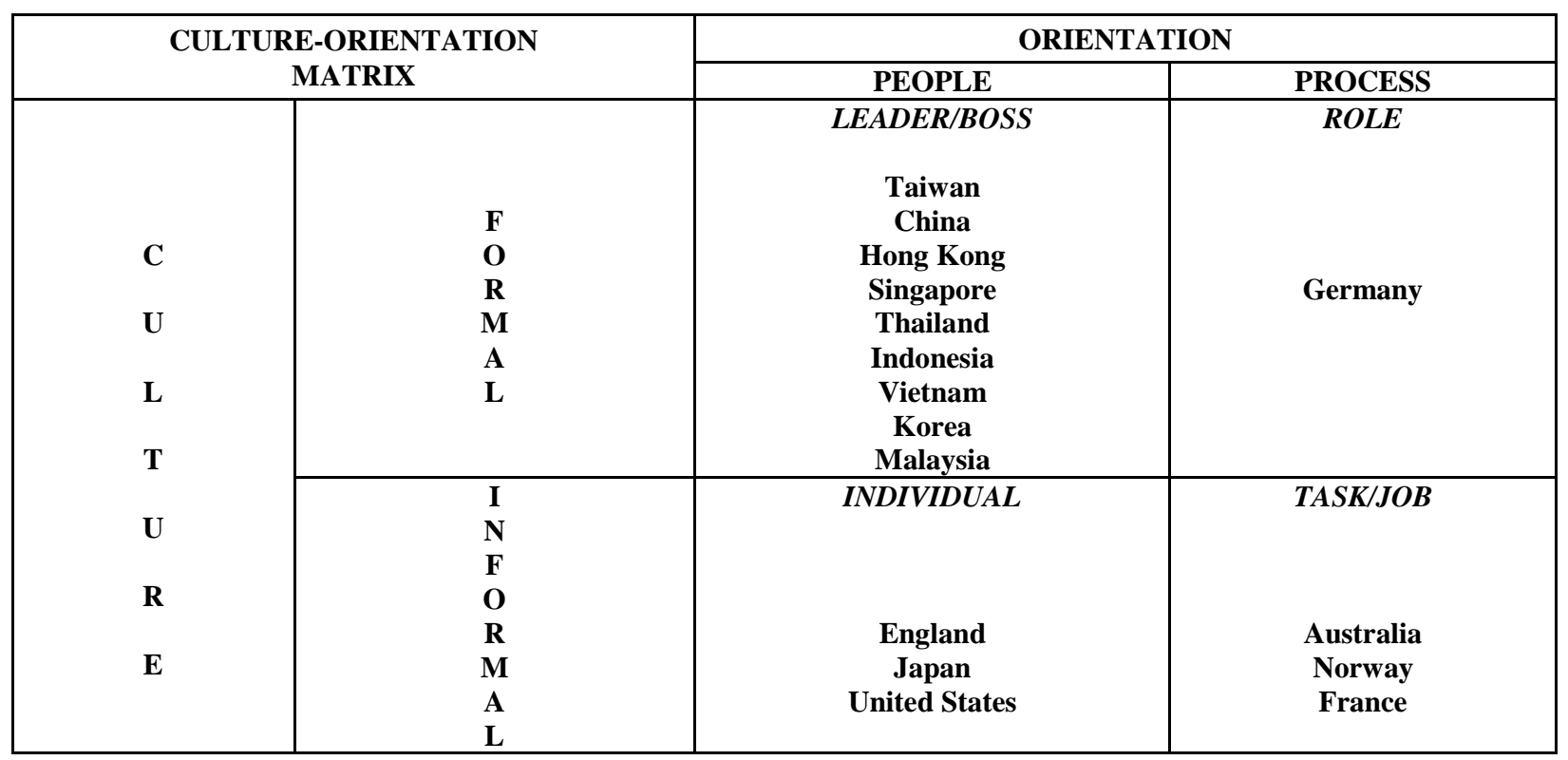




\section{Cultural Orientations And Information Technology}

Applying this model to the implementation of Information Technology, we need first to understand the 4 different IS strategies and IS characteristics associated with each strategy. That is, four strategies have been identified for pursuing Information Systems around the world. They include: Multinational, International, Global and Transnational, each with their unique characteristics and differing IS needs (Bartlett and Ghoshal, 1995; Jarvenpaa and Ives, 1994).

\section{Information Technology Strategies}

Multinational Strategy focuses on national responsiveness, deals with varying needs of many different markets, products, suppliers and customers. Each national unit responds quickly to local uncertainties, and each unit is isolated from others.

Global Strategy is concerned with the uniformity of world operations and strives for efficiency and coordination across national units. There is a tendency to ignore the diversity of local markets with key product and HR decisions made at the home office and implemented on a worldwide basis.

International Strategy allows for a great deal of discretion in adopting and modifying products directed by headquarters. It is dependent on the parent company for new products and technology know-how and the focus is on shared learning and the diffusion of innovations.

Transnational Strategy strives to be competent in all three strategies by developing and introducing new products rapidly throughout its global base, achieving economies of scale, and remaining responsive to local needs.

\section{Information Systems Characteristics Needs}

Multinationals have different data processing centers located in different countries, their information architectures are decentralized, and summary information is reported to the parent company from each separate entity

Global organizations have integrated applications distributed throughout the entire processing system. Information sharing is high across countries - but routine \& structured. IS structures are tightly centralized and there is a need to manage several types of control information .

International corporations need to manage multiple perspectives with quick feedback and broad bandwidth. There is a network of workstations and the use of use of lateral organizational entities, such as task forces, liaisons, teams, etc., including electronic communication systems; e.g., (e-mail, voice-mail, video conferencing).

Transnationals should be formalized, structured, yet flexible for local IS. They need to have integrated databases for economies of scale and a high bandwidth messaging system. They use distributed architectures, yet access must be homogeneous within the entire system. Combining the IT strategies and the IS needs, one can visually view the match in table 3 .

One can easily make the case that cell 1 in table 2 of the model reflects those cultures that would easily fall into the Transnational Strategy, with its emphasis on formal and structured orientation; the same for cell 2 as Role with its emphasis on centralization, uniformity, etc., cell 3 as Self, with emphasis on Decentralization, and cell 4 as Task, with its emphasis on independence, etc. Comparing table 2, with the various cultures in table 3, one can adopt a management style to pursue when implementing information technology in a particular society. For example, in implementing IT in Germany, an American manager would rely upon formalized procedures and procedures, detailing the activities to be covered. Perhaps the German orientation explains their development and adoption of SAP, a very formalized and structured system. 
Table 3

IS Strategies and IS Needs

\begin{tabular}{|c|c|}
\hline Strategy: Transnational & Strategy: Global \\
IS Needs: Formal, Structured, Flexible & IS Needs: Integrated, Uniform, Centralized \\
\hline Strategy: Multinational & Strategy: International \\
IS Needs: Decentralized, Many Data Systems & IS Needs: Independent with Multiple Perspectives \\
\hline
\end{tabular}

\section{Discussion}

Obviously, the application is not as simple as it seems. While it can be used in trying to understand cross-cultural differences, a few points need to be made. One, while many of the nationalities clearly fall into the cells as indicated, there are some situations whereby further refinement is needed. For example, the Germans fall into cell 2, with an orientation toward rules and regulations, and which appears to be characteristic of that society. However, a closer look at the data indicates that the males are the ones who overwhelmingly orient toward Formal-Role, while the majority of the females in the study orient toward Formal-Power. They are both formal in their orientation, but females indicate that they feel comfortable taking direction and look to the manager for all of her needs on the job. Again, these results tend to support the "so-called" national character of the Germans (both male and female). We must bear in mind that this not a negative finding. That is, the results do help us to distinguish between sub-cultures (based on gender) in a society. Therefore, we now know that we can approach a German male in one orientation, and at the same time, treat a German female differently.

Yet, even with these differences, we can learn from this study the variables of importance to nationalities around the world and from that prepare ourselves on the best approach to maximize their potential for the good of the company.

\section{Conclusions}

It is a given that groups form the basic structure of organizations. And, it is also a given that work is more often than not performed by groups in an organization. Our problem today is that we do not have homogenous groups from the same nation - or culture. In our global economy, we have a mixture of Japanese, Germans, Australians, Americans, etc., - all working within the same company, and their relationship can effect productivity. That is, actual productivity depends on how well the groups collaborate and uses its resources to accomplish the task. Cultural diversity makes group functioning more difficult. This is due to the fact that people see situations and understand them in different ways. It becomes increasingly troublesome to reach agreements. Misinterpretation, mis-perception, mis-evaluation and mis-communication are more likely to arise. The consequences are increased stress levels due to disagreements on expectations, the correctness of information and the particular decisions which must be taken, and who is to make them. Diversity increases the complexity, ambiguity and confusion in an organization. This has implications on costs. To address these issues, to insure that we maximize human performance within an organization, we need to become culturally-competent.

The first step consists of becoming conscious of one's own cultural orientation. For example, a great many Americans have a tendency to encourage "participating management." While proper in an American setting, if one would suggest it to Thai employees working for you, they would smile and say to themselves why are you asking me to decide - that is your job - just tell me what to do - period. Therefore, your action may not be the best - based on your cultural orientation.

The second is to know other cultures. That is, one must learn to recognize practices and values from other cultures and to use them in the right context. Therefore, more studies along these lines on cross-cultural differences 
can go a long way to bridge the gap between what we know and how to use that knowledge. This knowledge would also help to better refine and apply the model proposed within this paper.

In summary, IT has been instrumental in contributing to the effectiveness of organizations striving for competitive advantage. New developments and applications of IT have assisted many organizations, in many industries, to maximize the potential to exceed previous expectations on a global scale from a competitive standpoint. At the same time, students of IT have been exposed to, and educated in, a discussion of the multitude of variables that can impact on an organization's effectiveness. We have seen how IT can compete better with its rivals, suppliers, buyers, and potential entrants. We have seen how IT can impact organizational effectiveness by considering contributory studies from the fields of sociology, psychology, engineering, organizational behavior, and especially management. From this research, it became apparent, as Orlikowski and Baroudi (1991) indicated, that various research philosophies can offer a good perspective on the phenomena of interest in information systems research.

Researchers of IT have made great strides in identifying and isolating those variables which can advance the study of information technology and its contribution to the success of an organization. This practice needs to continue and all internal and external variables which could have an impact on the potential success of an organization need to be considered in order to promote the use of IT for the good of the organization and the individuals in the organization. This research can make a contribution to the study on the influence of culture and IT on an organization, and those variables that we need to understand.

As Fiedler, et. al. (1996), point out, additional research is needed into the benefits of matching IT and organization structure..The research presented here will contribute to the advancement of IT and organizational success, in that IT has both social and material properties, because it is physically and socially constructed by subjective human action, while at the same time, objectified and reified through institutionalization (Orlikowski and Robey, 1991). In essence, the cultural orientation of the individual operating within his culture is a major key variable to consider in the implementation of Information Systems.

\section{References}

1. Cartwright, S. and C. L. Cooper, "The Role of Culture Compatibility in Successful Organizational Marriage." Academy of Management Executive, 1993, (7), pp. 57-70.

2. Bartlett, C. A. and S. Ghoshal, Transnational Management: Text, Cases, and Reading in Cross-Cultural Management, $2^{\text {nd }}$ edition, Irwin, 1995.

3. Earley, P.C.,"'East Meets West Meets Mideast: Further Explorations of Collectivistic and Individualistic Work Groups." The Academy of Management Journal, 1993, (36), 319-345.

4. $\quad$ Erez, M., and P. C. Earley, Culture, Self-identity, and Work, New York, Oxford University Press, 1993.

5. $\quad$ Ferraro, G.P., The Cultural Dimensions of International Business, 2d ed. NJ, 1994.

6. Francesco, A. M. and B.A. Gold, International Organizational Behavior, Prentice Hall, NJ, 1998.

7. Gannon, M. J, Understanding Global Cultures, Sage, Thousand Oaks, 1994.

8. Garland, J. and R. N. Farmer, International Dimensions of Business Policy and Strategy, Kent Publishing Co., Boston, 1986.

9. Gordon, G. G., "Industry Determinants of Organizational Culture.” Academy of Management Review, 1991, (16:2).

10. Fiedler, K. D., V. Grover, and J. T. C. Teng, "An Empirically Derived Taxonomy of Information Technology Structure and its Relationship to Organizational Structure," Journal of Management Information Systems, Summer 1996, (13:1), pp. 9-34.

11. Harrison, R., "Understanding Your Organization's Character," The 1975 Annual Handbook for Group Facilitators, 1975, pp. 199-209.

12. Hofstede, G., B. Neuijen, D. D. Ohayv, and G. Sanders, "Measuring Organizational Cultures: a Quantitative Study Across Twenty Cases," Administrative Science Quarterly, 1990, (35), pp. 286-316.

13. Hofstede, G., Culture's Consequences: International Differences in Work-related Values, Beverly Hills, CA: Sage, 1980. 
14. Hofstede, G., "Cultural Constraints in Management Theories," Academy of Management Executive, 1993, $(7: 1)$.

15. Hunger, J. D. and T. L. Wheelen, Strategic Management, Addison-Wesley. New York, 1995.

16. Jarvenpas, S. I. and B. Ives, "The Global Network Organization of the Future: Information Management Opportunities and Challenges", Journal of Management Information Systems, (10:4), Spring 1994, pp. 25-57.

17. Jin, P., "Work Motivation and Productivity in Voluntarily Formed Work Teams: A Field Study in China Organizational Behavior and Human Development Processes," Journal of Applied Social Psychology, 1992.

18. Joynt, P. and M. Warner, Managing Across Cultures: Issues and Perspectives, International Thomson Business Press, London, 1996.

19. Kabanoff, B., R. Waldersee, and M. Cohen, "Espoused Values and Organizational Change Themes," Academy of Management Journal, 1995, (38), pp. 1075-1104.

20. Kabanoff, B., and J. Holt, "Changes in the Espoused Values of Australian Organizations 1986-1990," Journal of Organizational Behavior, 1996, (17), pp. 201-219.

21. Klein, A.A. R.R. Masi, and C.B. Weidner, "Organizational Culture, Distribution and Amount of Control and Perceptions of Quality," in Group \& Organization Management, 1995.

22. Kovach, K. A., "Employees Motivation: Addressing a Crucial Factor in Your Organization's Performance," in Employment Relations Today, Summer 1995.

23. Meier, G. M., The International Environment of Business: Competition and Governance in the Global Economy, Oxford University Press, New York, 1998.

24. Merchant, J. E., "International Cultural Issues: A Comparative Study of Organizational Orientations in Five Countries," in The Changing Environment of International Business, Academy of International Business, San Francisco, May 1994.

25. Merchant, J. E., "Organizational Culture: A Study of the Cultural Orientation of Employees in Nine Countries," in Proceedings of the Ninth World Productivity Congress, June 1995.

26. Merchant, J. E. "The Work Ethic of Chinese Employees in China, Taiwan and Hong Kong: An Empirical Investigation," in Proceedings of the First Asia Pacific DSI Conference, June 1996.

27. Merchant, J. E. "Determinants of Corporate Success: One View of Comparative Work Values of Australians and Americans", Proceedings of the Fourth International Meeting, Decision Sciences Institute, July 1997.

28. Nahavandi, A. and E. Aranda, "Restructuring Teams for the Re-engineered Organization." Academy of Management Executive, 1994, (8:4).

29. O'Reilly, C. A., III., J. Chatman, and D. F. Caldwell, 1991, "People and Organizational Culture: a Profile Comparison Approach to Assessing Person-organization Fit," Academy of Management Journal, (34), pp. 487-516.

30. Orlikowski, W. J. and J. Baroudi, "Studying Information Technology in Organizations: Research Approaches and Assumptions," Information Systems Research, March 1991, (2:1), pp. 1-28.

31. Orlikowski, W. J. and D. Robey, "Information Technology and the Structuring of Organizations," Information Systems Research, November 1991, (3:2), pp. 143-169.

32. Rollins, T., "Two Studies Define Link Between Corporate Culture and Business Performance," in Employment Relations Today, Summer 1995.

33. Ruhe, J. A., "Effects Of Leader Sex And Leader Behavior On Group Problem-Solving," Proceedings of the American Institute of Decision Sciences, Northeast Division, 1978, pp. 123-127.

34. Schneider, S., and A. DeMeyer, "Interpreting and Responding to Strategic Issues: the Impact of National Culture," Strategic Management Journal, 1991, (12), pp. 307-320.

35. Shane, S., "The Effect of National Culture on the Choice Between Licensing and Direct Foreign Investment," Strategic Management Journal, 1994, (15), pp. 627-642.

36. Shaw, M. E., Group Dynamics: The Psychology Of Small Group Behavior, New York: McGraw-Hill, 1983.

37. Sheridan, J. E. “Organization Culture and Employee Retention,” Academy of Management Journal, 1992.

38. Silverthorne, C. P., "Work Motivation in the United States, Russia and the Republic of China (Taiwan)," in Journal of Applied Psychology, 1992. 
39. Steiner, I. D., Group Process and Productivity, New York: McGraw-Hill, 1972.

40. Shweder, R. A., and R. A. LeVine, Culture Theory: Essays on Mind, Self, and Emotion, New York: Cambridge University Press, 1984.

41. Triandis, H. C., "Cross-Cultural Industrial and Organizational Psychology," in H. C. Triandis, M. D. Dunnette, and L. Hough (eds.), Handbook of Industrial and Organizational Psychology, 2nd ed., 4:103172. Palo Alto, CA: Consulting Psychologists Press, 1994.

42. Watson, W. E., Kumar, K., and Michaelsen, L. K., "Culturdiversity's Impact on Interaction Process and Performance: Comparing Homogeneous and Diverse Task Groups," 1993, Academy of Management Journal. 36:590-602.

43. Yip, G. S., Total Global Strategy. Prentice-Hall, New Jersey, 1995.

Notes 